\title{
PROGRESSIVE RESISTIVE LOADING ON ACCESSORY EXPIRATORY MUSCLES IN TETRAPLEGIA
}

\section{P Gounden}

\begin{abstract}
SUMMARY
To investigate the effects of progressive resistive loading on accessory expiratory muscles in tetraplegia, 40 such patients undergoing standard pulmonary rehabilitation were randomly assigned to control $(n=20)$ and experimental $(n=20)$ groups. In total there were 8 women and 32 men with an average age of 31 years. Their lesions were between the fifth and eighth cervical segments. The majority of the patients sustained their injury during motor vehicle accidents.

Prior to training, measurements of maximum expiratory mouth pressure and vital capacity were obtained from each group. The experimental group underwent eight weeks of training. The training involved the use of the PFLEX muscle trainer which allowed the patient to expire against a predetermined resistance. The initial resistive load was set at a level equivalent to 60 percent of the patient's maximum expiratory mouth pressure. Each subject was required to train for half an hour each day for six days a week. The resistive load was increased at two weekly intervals to ensure optimal loading throughout the training period.

The control group was excluded from any form of strenuous training, but continued with the standard pulmonary care which involved conventional breathing exercises and assistance in coughing.

The eight week long course of progressive resistive loading on accessory expiratory muscle showed a significant improvement in mean vital capacity from $1.48 \mathrm{~L}$ to $1.98 \mathrm{~L}(p=0.0001)$ and $a$ dramatic improvement in mean expiratory muscle strength from $43.76 \mathrm{cmH}_{2} \mathrm{O}$ to $\left.68 \mathrm{cmH}_{2} \mathrm{O}\right)(p=0.0001)$. Comparison of the values in the control group which were obtained eight weeks apart, showed no significant changes.

The present finding that expiratory muscle strength in tetraplegics can be improved with specific training has important therapeutic implications. The increased PEmax should enable these subjects to generate higher intrathoracic pressure swings during coughing.

Long term controlled studies should now be performed to determine the effects of this procedure on the clearance of bronchial secretions in such subjects.
\end{abstract}

\section{INTRODUCTION}

The growing incidence of spinal cord injuries in South Africa is directly related to physical injuries occurring as a result of motor vehicle accidents, interpersonal violence and sporting activities.

The most common location of these injuries is the cervical spine. The figures relating to the incidence of cervical cord damage in South Africa are comparable to those available for other Western nations. In 1987 the Conradie Hospital in the Cape Province (one of the leading spinal care centres in South Africa) estimated that fifty percent of all spinal injuries for that year involved the cervical spine.

Pulmonary complications present a major threat to the lifespan of the patient suffering from a complete lesion at any level of

\section{- Poobalam Gounden PhD Physiotherapy}

University of Durban-Westville, King Edward VIII Hospital,

Natal University - Faculty of Medicine

\section{OPSOMMING}

In 'n studie om die effekte van progressiewe weestandslading op die aksesoriese spiere in kwadruplee te bepaal, is $\mathbf{4 0}$ pasiënte wat gestandariseerde pulmonêre rehabilitasie ondergaan, gebruik. Hulle is blindelings verdeel in 'n kontrole $(n=20)$ en 'n eksperimentele $(n=20)$ groep. Daar was 8 vroulike and 32 manlike pasiënte met 'n gemiddelde ouderdom van 31 jaar. Hul letsels was tussen C5 en C8. Die meeste pasiënte het hul beserings tydens 'n motorongeluk opgedoen.

Voor oefening is die maksimum ekspiratoriese monddruk en vitale kapasiteit gemeet in beide groepe. Die eksperimentele groep het $\mathbf{8}$ weke lank 'n oefeningprogram ondergaan. Die oefening het die gebruik van die PFLEX spierbouer ingesluit waardeur die pasiënt toegelaat is om teen ' $n$ voorafbepaalde weerstand uit te asem. Die aanvangsweerstandslading is gestel on 'n vlak gelyk aan 60 persent van die pasient se maksimum ekspiratoriese monddruk. Elke pasiënt moes vir 'n halfuur elke dag, ses dae per week, oefen. Die weerstandslading is twee weekliks verhoog om optimale lading tydens die oefenperiode te behou.

Die kontrole groep is weggehou van enige vorm van swaar oefening, maar het wel voortgegaan met die normale pulmonêre versorging, nl. konvensionele asemhalingsoefeninge en hulp met hoes.

Die 8 week lange kursus van progressiewe weerstandslading op die aksesoriese ekspiratoriese spiere het 'n betekenisvolle verbetering in die algemene vitale kapasiteit, van $1.48 \mathrm{~L}$ tot $1.98 \mathrm{~L}(p=0.0001)$ meegebring. ' $n$ Vergelyking in die waardes in die kontrole groep voor en na 8 weke het geen merkwaardige veranderinge getoon nie.

Die huidige bevinding dat ekspiratoriese spiersterkte in kwadrupleë verbeter kan word met spesifieke oefening, bring mee belangrike implikasies. Die stygende PEmax behoort pasiënte intra-torakale drukveranderinge tydens hoes te ge日. Lang termyn beheerde studies behoort nou gedoen te word om die effekte te bepaal wat hierdie prosedure op die mobilisering en verwydering van sekresies op sulke pasiënte het.

the cervical cord (tetraplegia). The respiratory insufficiency in tetraplegia is secondary to paralysis of the intercostal and abdominal muscles $1,23,4,5,6,7,8$.

The expiratory muscle force is reduced to less than 40 percent of it normal values causing a serious impairment on the patient's ability to cough $9,10,11,12$. In addition to this, vital capacity has been shown to drop to levels less than 50 percent of its normal values $3,13,14,15,9$

These factors are closely association with the incidence of hypostatic pneumonia which has been shown to be one of the leading causes of death in tetraplegia $16,17,18,19,20,21,22$.

In addition to this compromised pulmonary defence system the tetraplegic also develops ventilatory muscle weakness caused by structural changes in the muscles that have been spared by the lesion.

CAPE TOWN: Full-time Physiotherapist needed for private practice in Blaaubergrand. No hospital work. Contact: P Vorster - Tel: (021) 557-4515 (w); (021) 52-5585 (h) 
A patient with a low lesion may have partial or total innervation to the diaphragm, sternocleido-mastoid, scalene and trapezius muscles, which serve a vital role in maintaining adequate ventilatory function.

The importance of preventative respiratory therapy was recently highlighted by $\mathrm{Carter}^{3}$, an internationally respected spinal care specialist. In a recent publication he expressed the following concern: "Certainly there are few, if any, areas elsewhere in the field of medicine that require treatment prior to the onset of pathology as does the respiratory muscle weakness in spinal cord injury." $\mathrm{He}$ considers the conditioning of ventilatory muscle to be an important part of the total pulmonary rehabilitation programme ${ }^{3}$. This could be accomplished with the aid of a specific training programme which involves progressive loading of the accessory muscles of ventilation.

Ventilatory muscle training in clinical practice is still in the experimental stage and the scientific basis for training has as yet not been firmly established ${ }^{424,25,26,8,27}$. Leith and Bradley, after a six week training programme using isocapnic hyperpnoea achieved marked improvement in ventilatory muscle strength and endurance among a group of normal subjects ${ }^{27}$.

In 1980, Gross and co-workers tested the effect of resistive inspiratory muscle training on a small group of tetraplegics and found favourable results both in ventilatory muscle strength and endurance $^{28}$.

This study was designed to test the effect of progressive resistive loading on accessory expiratory muscles in tetraplegics with low cervical cord lesions. The rationale for training was based on evidence that tetraplegics retrain the use of the clavicular part of the pectoralis major and latissimus dorsi muscles during active expiration $^{16}$. This is a poorly researched area despite the fact that the tetraplegic suffers a far greater impairment in expiratory function than in inspiratory function ${ }^{16}$.

\section{METHOD}

Forty sedentary tetraplegics were studied.

There were eight females and thirty two males. Thirty three patients were registered in-patients at hospitals, while six were in institutions for the disabled. The remaining patient was a successful businessman who lived on his own. Their demographic data are detailed in Tables 1 and 2 . Approximately 40 percent of them spent most of their time in bed. They were put in supported sitting positions for only short periods. The other 60 percent spent part of the day in wheelchairs and the rest of the day in bed.

Most were receiving some form of rehabilitative procedure,

TABLE 1: CLINICAL DETAILS OF THE PATIENTS IN THE CONTROL GROUP

\begin{tabular}{|c|c|c|c|c|c|}
\hline $\begin{array}{l}\text { CASE } \\
\text { NO }\end{array}$ & AGE & SEX & $\begin{array}{l}\text { LEVEL OF } \\
\text { SPINAL LES }\end{array}$ & $\begin{array}{l}\text { NATURE OF } \\
\text { ON INJURY P }\end{array}$ & $\begin{array}{l}\text { POST-INJURY } \\
\text { PERIOD-MONTHS }\end{array}$ \\
\hline 1 & 25 & $\mathbf{M}$ & C6 & MVA & 4 \\
\hline 2 & 28 & $\mathbf{M}$ & $\mathrm{Cl}$ & MVA & 4 \\
\hline 3 & 24 & $F$ & $\mathrm{C7}$ & MVA & 4 \\
\hline 4 & 27 & $F$ & C5/6 & MVA & 25 \\
\hline 5 & 34 & M & C6 & DIVING INJURY & 108 \\
\hline 6 & 37 & M & C5/6 & MVA & 17 \\
\hline 7 & 30 & M & C5/6 & MVA & 132 \\
\hline 8 & 28 & M & C6 & MVA & 14 \\
\hline 9 & 21 & M & C6 & MVA & 14 \\
\hline 10 & 39 & M & $\mathrm{C} 5 / 6$ & MVA & 192 \\
\hline 11 & 24 & M & C5 & STAB WOUND & 33 \\
\hline 12 & 39 & M & C6 & MVA & 35 \\
\hline 13 & 26 & M & $\mathrm{C7}$ & MVA & 27 \\
\hline 14 & 25 & M & C5/6 & MVA & 4 \\
\hline 15 & 39 & $\mathbf{F}$ & $\mathrm{C7}$ & MVA & 36 \\
\hline 16 & 40 & M & $\mathrm{C7}$ & MVA & 84 \\
\hline 17 & 64 & $\mathbf{M}$ & C6 & FALL & 4 \\
\hline 18 & 40 & $F$ & C6/7 & FALL & 4 \\
\hline 19 & 30 & $F$ & C5 & FALL & 4 \\
\hline 20 & 55 & $\mathbf{M}$ & C5/6 & FALL & 6 \\
\hline
\end{tabular}

TABLE 2: CLINICAL DETAILS OF THE PATIENTS IN THE EXPERIMENTAL GROUP

\begin{tabular}{|c|c|c|c|c|c|}
\hline $\begin{array}{l}\text { CASE } \\
\text { NO }\end{array}$ & AGE & SEX & $\begin{array}{l}\text { LEVEL C } \\
\text { SPINAL LE }\end{array}$ & $\begin{array}{l}\text { OF NATURE OF } \\
\text { SION INJURY PEF }\end{array}$ & $\begin{array}{l}\text { T-INJURY* } \\
\text { D-NONTHS }\end{array}$ \\
\hline 1 & 25 & $\mathbf{M}$ & $\mathrm{C5} / 6$ & STAB WOUND & 12 \\
\hline 2 & 30 & $\mathbf{M}$ & $\mathrm{C} 6 / 7$ & MVA & 31 \\
\hline 3 & 27 & $\mathbf{M}$ & $\mathrm{C} 5 / 6$ & FALL & 8 \\
\hline 4 & 33 & $\mathbf{M}$ & $\mathrm{C7}$ & MVA & 12 \\
\hline 5 & 30 & M & C6 & DIVING INJURY & 36 \\
\hline 6 & 17 & $\mathbf{M}$ & $\mathrm{C} 5 / 6$ & FALL - MOUNTAIN & 5 \\
\hline 7 & 16 & M & C6 & RUGBY INJURY & 5 \\
\hline 8 & 35 & $\mathbf{M}$ & $\mathrm{C7}$ & MVA & 4 \\
\hline 9 & 22 & M & C6 & MVA & 7 \\
\hline 10 & 20 & $\mathbf{M}$ & $\mathrm{C} 6 / 7$ & MVA & 7 \\
\hline 11 & 24 & M & C6 & MNA & 48 \\
\hline 12 & 24 & $\mathbf{F}$ & C6 & MVA & 60 \\
\hline 13 & 45 & $F$ & C5/6 & MVA & 4 \\
\hline 14 & 31 & M & $\mathrm{C} 5 / 6$ & MVA & 9 \\
\hline 15 & 34 & $\mathbf{M}$ & C5 & MNA & 5 \\
\hline 16 & 39 & M & $\mathrm{C7}$ & STAB WOUND & 159 \\
\hline 17 & 23 & $M$ & $\mathrm{C7}$ & DINING INJUJRY & 31 \\
\hline 18 & 30 & M & C6 & MVA & 46 \\
\hline 19 & 24 & $\mathbf{M}$ & $\mathrm{C7}$ & FALL & 38 \\
\hline 20 & 27 & $F$ & C6 & MVA & 21 \\
\hline
\end{tabular}

either at the Occupational or Physiotherapy Departments. Their programmes were at a low intensity level with either twice or thrice a week attendances. None of these patients was involved in any form of strenuous upper body training prior to or during the study period. They were all in a clinically stable state and did not have any respiratory symptoms apart from the restrictive respiratory compromise secondary to ventilatory muscle paralysis. Subjects were randomly assigned to two groups, an experimental group and a control group. There were twenty patients in each group.

\section{EVALUATION OF LUNG FUNCTION AND VENTILATORY MUSCLE STRENGTH PRIOR TO TRAINING}

Before measurements were taken, each patient was familiarized with the experimental techniques so that learning would not produce spurious results. Vital capacity and maximum static respiratory pressures were measured in all patients in two study positions (supported sitting and supine position). The vital capacity was measured on a Vitalograph Spirometer (from Medical Insturmentation). Repeated determinations were made until two technically satisfactory measurements were obtained. The highest value obtained was recorded. The order of the positions in which the spirometric measurements were made was varied in random sequence.

\section{MEASUREMENTS OF VENTILATORY MUSCLE STRENGTH}

The PEmax ad the PImax were measured on the Inspiratory/Expiratory Force Meter (Figure 1). The PEmax was measured at total lung capacity. After a maximum inspiratory effort the mouth piece was placed well into the mouth and the patient was asked to expire as forcefully and quickly as possible. The mean of three trials was recorded. This was followed by a short rest which lasted for approximately five minutes after which the PImax was measured as follows: After a maximum expiratory effort the subject was asked to inspire with maximum force. The method of documentation was the same as that for the PEmax values. The order of position in which the pressures were measured was varied in random sequence. The experimental group underwent specific training for 8 weeks while the control group continued to receive conventional therapy. The conventional therapy did not include any form of vigorous activity or resisted breathing manoeuvres. 


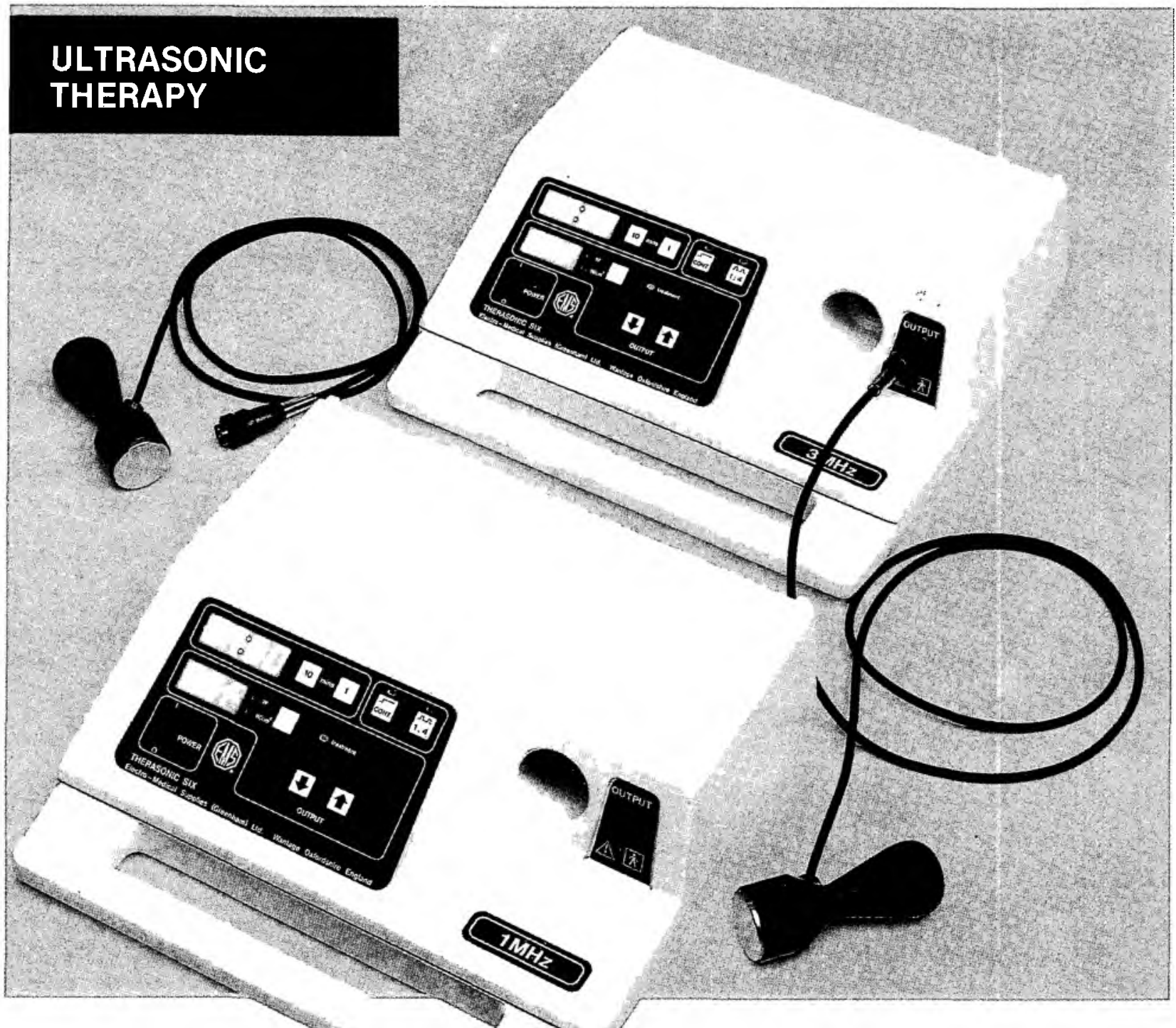

\section{Therasonic Six}

The Therasonic Six is the latest application by EMS of new technology to produce a single output, single frequency ultrasonic therapy unit. The Six incorporates many of the features of the more sophisticated 1032 unit - the same case, the same design of treatment head, the same superb-quality push button type of control panel; also the same waterproof carrying case (as an optional extral.

It is available in two versions - a $1 \mathrm{MHz}$ model and a 3 $\mathrm{MHz}$ model. Both models are identical in everything except the operating frequency.

The Therasonic Six weighs only $4.2 \mathrm{~kg}(9 \mathrm{lb})$. Facilitıes include:

1. 7 output levels $-0.1,0.2,0.5,0.75,1.0,1.5,2.5 \mathrm{w} / \mathrm{cm}^{2}$.

2. Pulsed and continuous modes.

3. Digital treatment timer.

4. Fully-immersible $5 \mathrm{sq} \mathrm{cm}$ treatment head (protected by automatic cut-out when not in patient contact).

5. Socket fitted to unit to allow for combination therapy (i.e. ultrasound with interferential, diadynamic, faradic).

\section{Brlef Technical Speciflcatlon}

Therasonlc Slx - 1 MHz Model and 3 MHz Model

Power input

Power consumption

Size

Weight

Classification

Frequency

Output

Pulse Duration

Pulse on/off ratio

Max. Output Intensity

Output Intensity Settings

Max. Output Power

Output Power Settings
$100,120,220,240 \mathrm{~V} \sim 50 / 60 \mathrm{~Hz}$ $45 \mathrm{~W}$

$320 \times 302 \times 110 \mathrm{~mm}$

$4.2 \mathrm{~kg}$

Class 1: Type BF (IEC 601-1: 1977)

$1.1 \mathrm{MHz}+/-5 \%$

(3 MHz Model - $3.4 \mathrm{MHz}+/-5^{\circ}$ Both continuous and pulsed $2 \mathrm{~ms}$

$1: 4$

2.5 Watts per square $\mathrm{cm}$

$0,0.1,0.2,0.5,0.75,1.0,1.5,2.5$ Watts per square $\mathrm{cm}$ $11.4 \mathrm{~W}$

(3 MHz Model - 9.7 W)

$0,0.4,0.9,2.2,3.3,4.5,6.7,11.2 \mathrm{~W}$ (3 MHz Model - 0, 0.4, 0.8, 2.0, 2.9, 3.9, 5.9, 9.7 W]

\section{FOR FULL DETAILS CONTACT}

\section{MEDICAL DISTRIBUTORS}

P O Box 3378 Johannesburg 2000 Phone: (011) 29-6931

P O Box 195 Cape Town 8000 Phone: (021) 47-4440

P O Box 5298 Durban 4000 Phone: (031) 37-1501

P O Box 6814 Pretoria $\quad 0001$ Phone: (012) 346-1269 


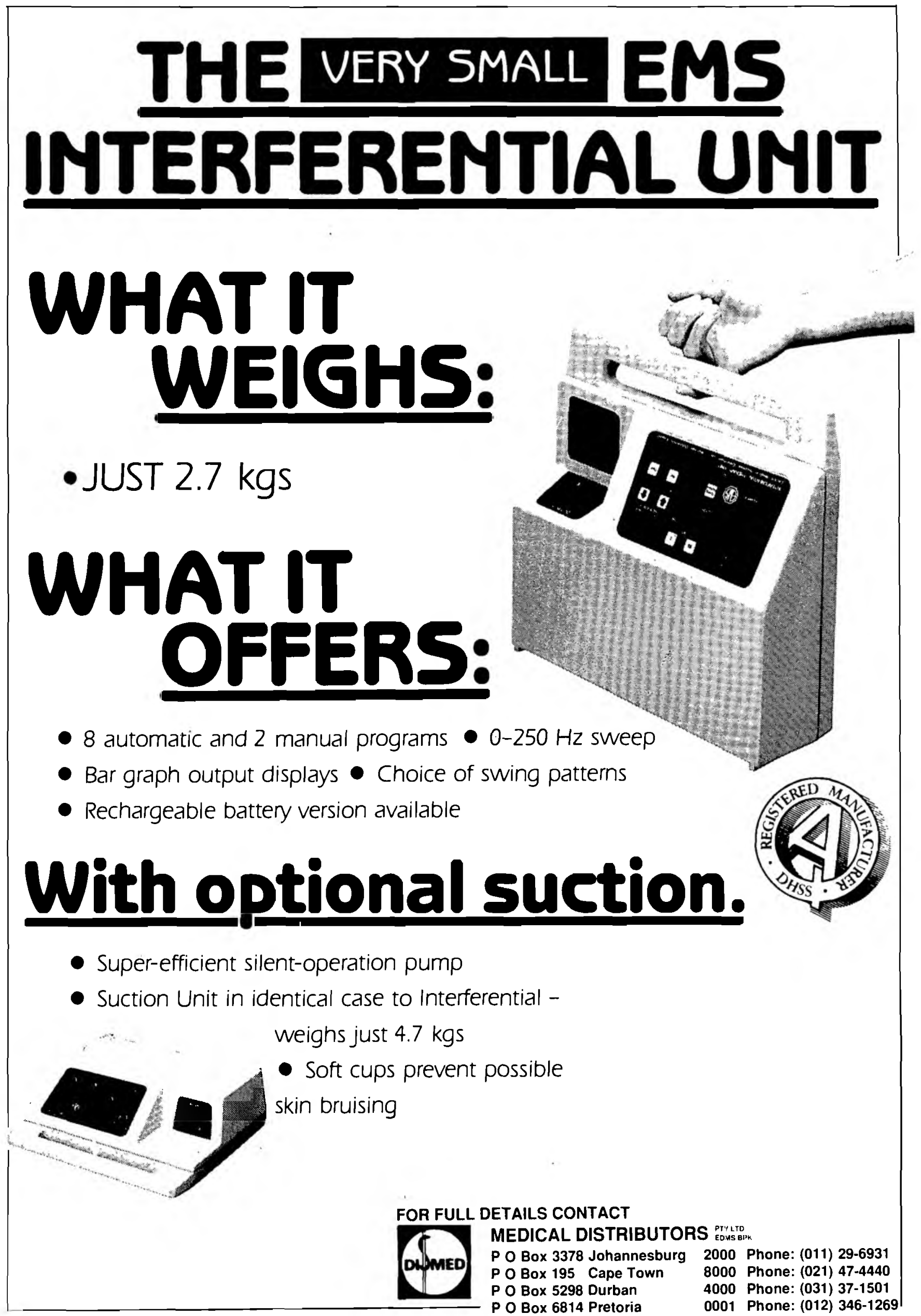




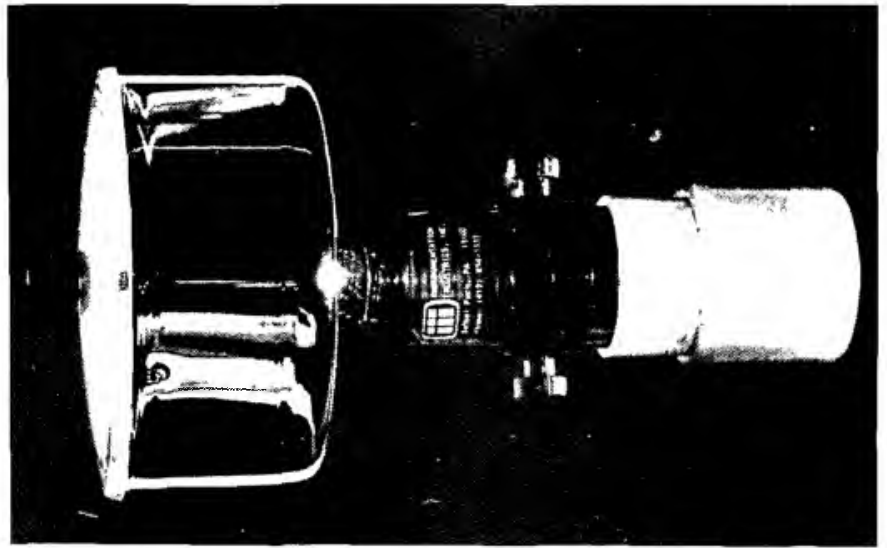

FIGURE 1: The Inspiratory/Expiratory Force Meter*

\section{THE EXERCISING APPARATUS THE PFLEX VENTILATORY MUSCLE TRAINER}

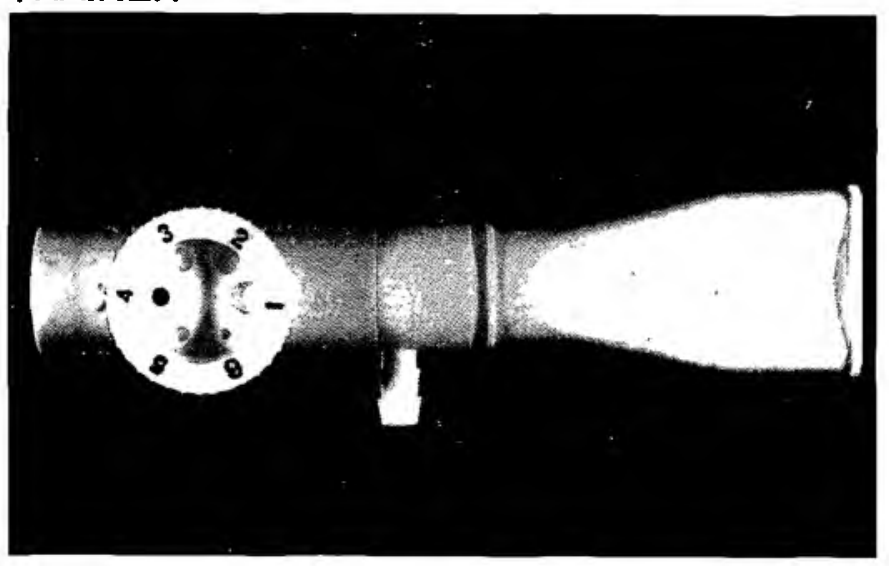

FIGURE 2: The PFLEX muscle trainer

This trainer was found to be the most effective and least expensive apparatus for the purpose of providing progressive resistive training to the accessory expiratory muscle ${ }^{29,30}$. The PFLEX trainer is a 5.7 centimeter long cylindrical plastic device with an opening at one end for the insertion of a plastic mouth piece and is sealed at the other end by a one-way valve (Figure 2). Breathing resistance is controlled by an adjustable dial mechanism with six settings located on the shaft of the device.

\section{THE METHOD OF SELECTION OF INDIVIDUAL INITIAL RESISTIVE LOAD}

It is important to select the correct threshold of training stimuli in order to generate an optimal effect on the accessory expiratory muscles.

The criterion for the selection of the initial resistance was based on principles recommended by Larson $^{31}$ and Sobush ${ }^{32}$. The orifice that offered a resistance equivalent to approximately 60 percent of his PEmax was selected to represent the initial resistive load for the particular patient. An optimal training load was crucial in ensuring maximal training effects. Larson has shown that a 30 percent training load was more effective than a 15 percent load in improving inspiratory muscle endurance. He recommended a heavier load for strength training ${ }^{31}$.

- From Boehringer Laboratories

** From Health Scan Medical Apparatus

\section{RESISTIVE TRAINING}

Once the initial load was determined all patients in the experimental group were ready to commence training after a full explanation of the technique. With the trainer device placed well into the patient's mouth he was instructed to inhale deeply through the nose and exhale forcefully into the trainer. The deep inspiratory phase was slow, allowing the patient to inspire at a relaxed pace with minimum effort. Each patient was shown the difference between inspiring through the nose and though the trainer. In this way inspiratory loading was minimised. Each training session lasted for approximately five to eight minutes and was repeated at least five times a day. Each patient was encouraged to exercise for a total period of at least half an hour per day. They exercised six days per week for eight weeks. The training was conducted either in the supported sitting or in supine position depending on the patient's ability to generate maximum expiratory muscle force in these positions. The position which yielded the greatest expiratory pressure was selected for training.

In order to gain maximal training effects the resistive load had to be maintained at an optimal level throughout the training period. This was done by increasing the resistance on the PFLEX trainer after every two weeks of training. Each adjustment in the resistance control increased the total resistance by five to 10 percent.

The training was supervised by the author and four research assistants. Supervision was on a daily basis for the first two weeks and then on alternate days for the rest of the training period. Subjects who stopped training for three consecutive days were considered detrained and were either removed from the study or rescheduled for another eight weeks of training. Measurement of vital capacity and static respiratory pressures in the experimental group were repeated after eight weeks of training. Similar measurements were obtained from the control group eight weeks after the first measurement.

\section{RESULTS}

The majority of the patients in the experimental group were well motivated and co-operative. Three patients were considered detrained in the first fortnight of training. Since this happened in the early stages in the study it was decided to reschedule the three patients for another full training period of eight weeks.

\section{STATISTICAL METHODS}

The student's paired ' $T$ ' test and the unpaired ' $T$ ' test were used for statistical analysis. A p-value less than 0.05 was considered significant.

\section{THE EFFECT OF TRAINING ON VITAL CAPACITY}

Two measurements were obtained from the control group. These were taken eight weeks apart. Seven patients in the control group showed greater values for vital capacity in the second measurement when compared with the measurements obtained in the first reading while nine patients showed lower values at the same reading. However, statistical comparison (paired ' $T$ ' test) between the first and second mean vital capacity measurements in the control group did not show significant difference $(\mathrm{p}=\mathbf{0 . 3 9 0 3})$ as shown in Table 3 .

The effect of training on the experimental group had a profound effect on the vital capacity measurements. Increases in post-training values were noted in 18 patients. Comparison between the pre- and post-training mean vital capacity values in the experimental group showed a significant difference $(p=0.0001$; Table 4$)$.

EQUIPMENT WANTED. Does anybody have any electrotherapy or gym equipment for sale? Plinths etc. would also be useful. Contact Sue Mars or Kathy Morley - Tel: (031) 22-3172 (w); (031) 21-5345 (h). 
TABLE 3: CHANGES IN VITAL CAPACITY IN THE CONTROL GROUP (MEASUREMENTS OBTAINED EIGHT WEEKS APART)

$\begin{array}{lccc}\text { Varlable Label } & \text { N } & \text { Mean (Litres) Std Dev } & \text { Std } \\ \text { BEFORE } & 20 & 1.52 & 0.79 \\ \text { AFTER } & 20 & 1.41 & 0.79 \\ \text { CHANGE AFTER-BEFORE } & 20 & -0.10 & 0.55 \quad p=0.3903\end{array}$

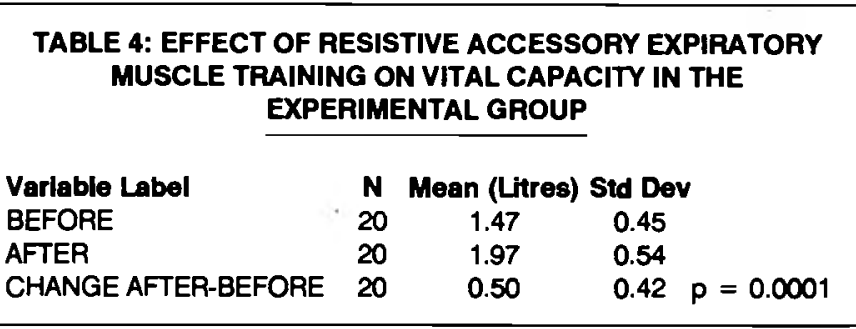

TABLE 5: CHANGE IN VITAL CAPACITY IN CONTROL GROUP COMPARED WITH CHANGE IN VITAL CAPACITY IN EXPERIMENTAL GROUP

$\begin{array}{cccc}\text { Group } & \text { Mean (Litres) } & \text { std Dev } & \\ \text { C } & -0.10 & 0.55 & \\ \text { E } & 0.50 & 0.42 & p=0.0004\end{array}$

The change in vital capacity in the control group compared with that of the change in the experimental group showed significant difference (Table 5).

Figure 3 (page 10), shows the mean change as well as changes in individual vital capacity measurements in both groups. The second set of values for the control group was obtained eight weeks after the first measurement whereas the values for the experimental group represent pre-and post-training measurements.

The steeper slope representing the mean change (broken line) in the experimental group implies that the proportional change was greater in this group.

\section{THE EFFECT OF TRAINING ON PEmax}

Twelve patients in the control group showed increases in PEmax values at the second measurement whereas five patients showed a decrease in PEmax. Comparison between the mean PEmax values obtained from first measurements with that obtained from the second set of readings showed no significant difference $(p=0.4629$; Table 6).

\section{TABLE 6: CHANGES IN PEmax MEASUREMENTS IN THE} CONTROL GROUP (OBTAINED EIGHT WEEKS APART)

Variable Label

BEFORE

AFTER

CHANGE AFTER-BEFORE

$\begin{array}{lcc}\text { No } & \text { Mean }\left(\mathrm{cmH}_{2} \text { O) }\right. & \text { Sid Dev } \\ 20 & 44.20 & 20.29 \\ 20 & 46.45 & 19.91\end{array}$

2.25

$13.43 p=0.4629$

TABLE 7: EFFECTS OF RESISTIVE ACCESSORY EXPIRATORY MUSCLE TRAINING ON PEmax IN THE EXPERIMENTAL GROUP 
FIG 3: THE EFFECT OF PROGRESSIVE RESISIIVE TRAINING THE EFFECT OF PROGRESSIVE RESISTIVE TRAINING
ON VITAL CAPACITY IN THE EXPERIMENTAL GROUP

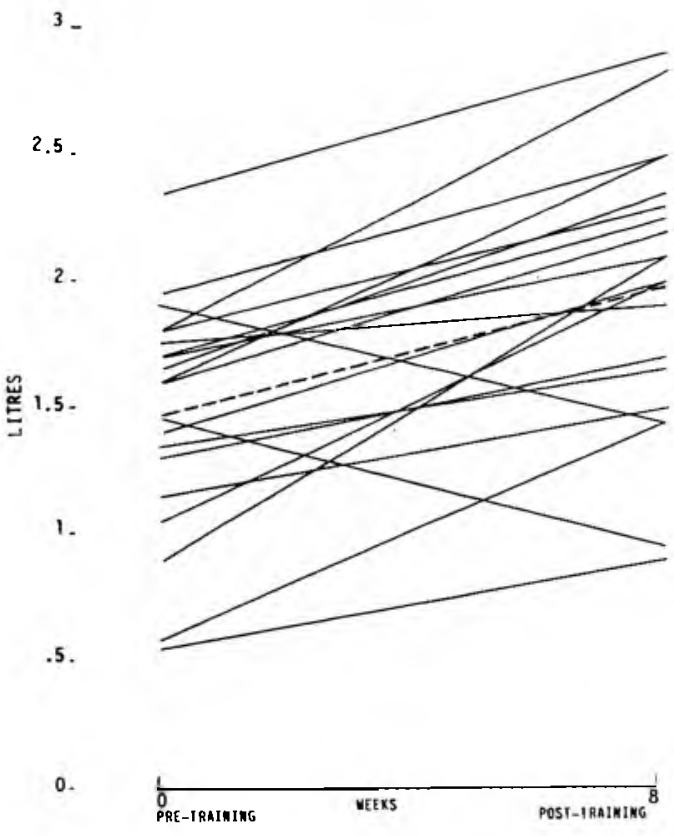

Fig 4: THE EFfect OF PROGRESSIVE RESISTIVe trainimg OM PEEaX OH THE EXPERIMEMTAL GROUP.
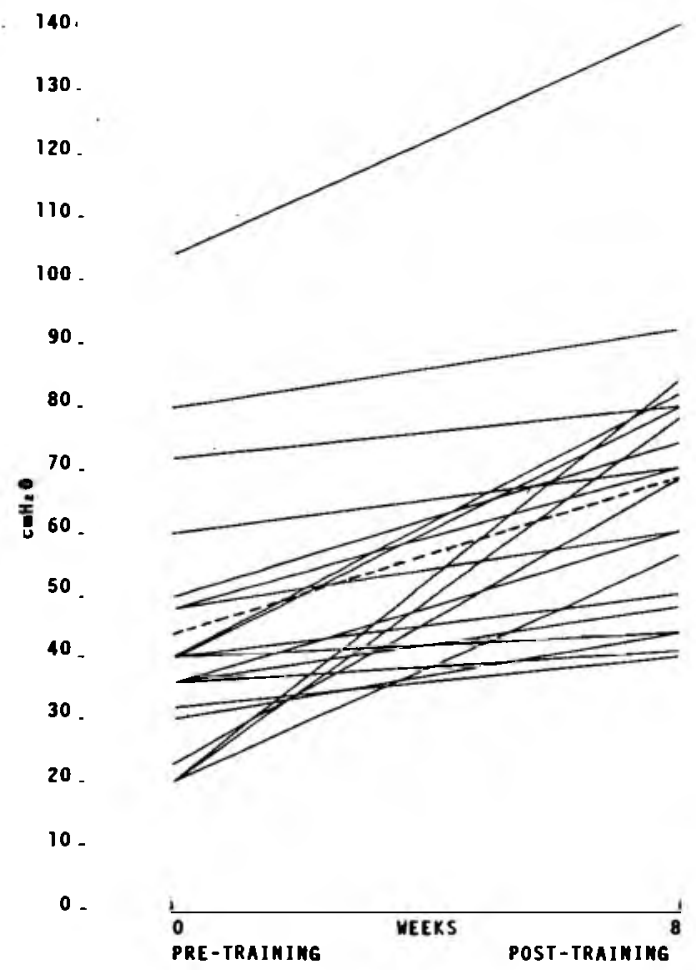

The selection of an appropriate training posture was based on the work undertaken in a preliminary study. This was necessary to standardise the exercise position in each patient. The patients were therefore instructed to train in a particular position from which the pre-and post-training measurements were also recorded. The maintenance of a single starting position was important to prevent adaptive changes in the muscle fibres caused by changes in posture as demon-
CHANGES IN VITAL CAPACITY IN THE CONTROL GROUP 3.5 - (MEASUREMENTS OBTAINED EIGHT WEEKS APART)

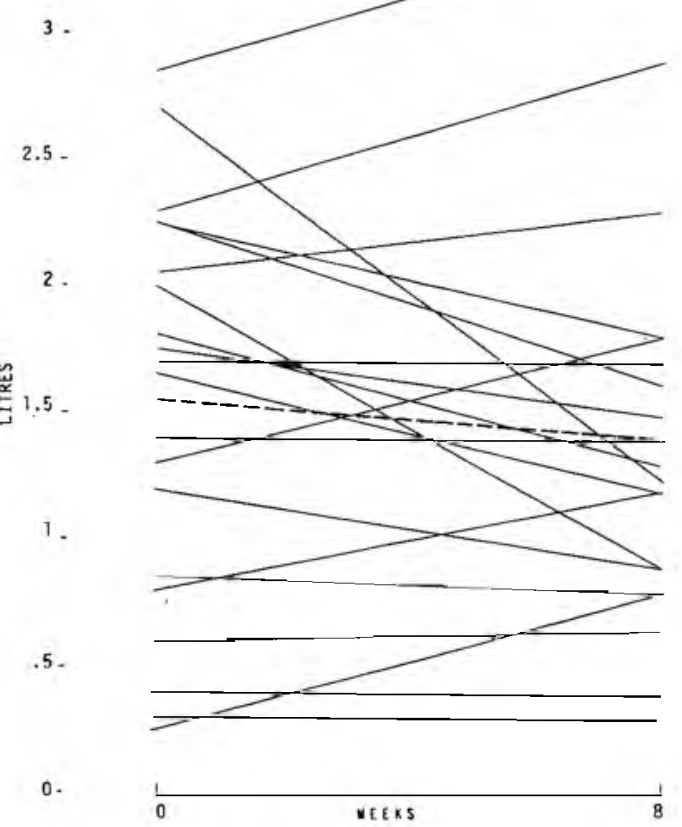

CHANGES IN PEmax IN THE CONTROL GROUP (MEASUREREMTS OBTAINED 8 MEEKS APART)

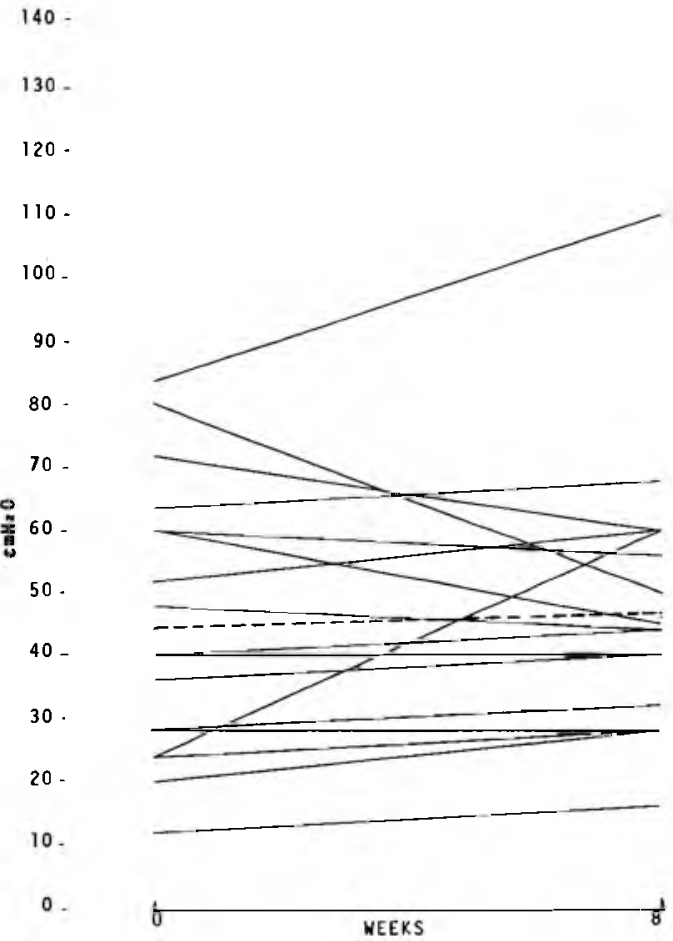

strated by Danon, Mortola and Miller ${ }^{41,42,43}$. Therefore, the improvements in exspiratory muscle strength as shown in this study cannot be attributed to adaptive changes in length tension ratio in the muscle fibres, which can sometimes be caused by postural changes ${ }^{44,43}$.

In order to achieve optimal training effects the breathing strategy was carefully controlled. Electromyographic examination of the accessory expiratory muscles undertaken in another preliminary 
study showed maximum motor unit activity during the forced resisted breathing following a deep inspiratory phase. During this forced phase the expiratory muscles were working concentrically against a predetermined resistance. It has previously been suggested that a strengthening programme should devote 75 percent of the training to concentric muscle work ${ }^{45}$. The deep inspiratory phase lengthened the inspiratory fibres and force expiratory phase cause concentric muscle work. This type of training caused intermittent loading on these muscles.

The improvements in PEmax measurements only became evident after the fourth week of training. These measurements showed negligible changes in the early stages of training. This meant that the increased in expiratory muscle potential could not be attributed to non-specific learning effect. The are in fact a reflection of the impact of a specifically designed training programme on ventilatory muscles.

The level of the lesions in the experimental group ranged from the fifth to the eighth cervical segment. Therefore, all the subjects in this group had at least a partial innervation of the clavicular part of the pectoralis major and latissimus dorsi muscles. The significant improvement in accessory expiratory muscle strength as represented by the increase in maximum expiratory mouth pressures could be attributed to several factors:

- An improvement which could be due to muscle fibre hypertrophy ${ }^{46}$.

- The threshold of training stimulus might have initiated the recruitment of a larger portion of the partially innervated muscles.

- Beside the known accessory expiratory muscles, the serratus anterior muscle as well as other upper thoracic muscles (spared by the lesion) may also have a role in the mechanism of active expiration in tetraplegia. The training stimulus might have recruited active contraction in these muscles.

There was a 16 percent improvement in the mean PImax signifying that inadvertent concentric conditioning of the inspiratory muscles in the experimental group resulted in minor changes in muscle strength.

Therapeutic intervention in the form of specific training was administered at various stages in the post-injury period. Some patients were studied four months after their injury while others were studied many years after the onset of their injury (Table 2). Positive training effects were achieved in all patients. This implied that tetraplegics, at various stages in their post-injury period, may benefit from this form of training.

The object of the study was to determine the effect of training on accessory expiratory muscles in tetraplegics.

The patients in the experimental group would not have been suitable to a scientifically viable study involving the quantification and shift of secretions. A study of this nature should be conducted only on patients with evidence of increased sputum yield.

The subjects in the experimental group were free of any respiratory infections at the time of the study. The selection criteria excluded patients with respiratory infections. Respiratory infection in any of the subjects in the experimental group would have had an adverse effect on their exercise tolerance. This would have produced misleading results.

A few patients form the experimental group, however, showed subjective evidence of improvement in the ability to cough. This ability to effect a productive cough might have been due to an improvement in expiratory muscle strength. Furthermore, it was not possible to report on the length of time for which the training effects would last since the measurements were not monitored longitudinally after the allotted period of eight weeks.

\section{CONCLUSIONS AND RECOMMENDATIONS}

The conclusions drawn from this study indicate that specific training involving progressive resistive loading on the accessory expiratory muscles significantly improves muscle strength. The study also showed that effective strength training should involve the use of near maximal resistances throughout the allotted training period. Clinical evidence showed enhancement in the patient's ability to cough.

Further carefully controlled long-term studies are recommended to investigate the effect of accessory expiratory muscle training on morbidity and morality in patients with complete lesions of the cervical cord. These would need to monitor, inter alia:

- The duration for which the beneficial effects are maintained after a single training period

- and consequently the frequency of such a training programme during rehabilitation

- the volume of sputum expectoration

- the incidence of infective complications.

The outcome of such studies will determine the long-term clinical value of ventilatory muscle training in tetraplegia.

\section{REFERENCES}

1. McCagg C. Post-operative management and acute rehabilitation of patients with spinal cord injuries. Orhop Clin Norh Am 1986; 17(1):171182.

2. Massery M. An innovative approach to assistive cough techniques. Top Acute Care Trauma Rehabil 1987; 1(3):73-85.

3. Carter R E. Respiratory aspects of spinal cord injury management. Paraplegia 1987; 25:262-266.

4. Clough P, Londenauer D, Hayes M, Zekany B. Guidelines for routine respiratory care of patients with spinal injuries. Phys Ther 1986; 66:13951402.

5. Alvarez S E, Peterson M, Lonsford B R. Respiratory treatment of adult patients with spinal cord injury. Phys Ther 1981;61:1737-1745.

6. Axen $\mathrm{K}$, Pineda $\mathrm{H}$ Schunfenthal $\mathrm{H}$, Haas F. Diaphragmatic function following cervical cord injury. Arch Phys Med Rehabil 1985;66:219-222.

7. McMichan J C, Michel L, Westbrook P R. Pulmonary dysfunction following traumatic quadriplegia: recognition, prevention and treatment. JAMA 1980;243:528-531.

8. Lerman R M, Weiss M S. Progressive resistive exercise in weaning high quadriplegics from the ventilator. Paraplegia 1987;25:130-135.

9. Robin MJ. Respiratorymonitoring in the intensive care unit. Am Rev Respir Dis 1988;138:1625-1642.

10. Fugl-Meyer A R. Effects of respiratory muscle paralysis in tetraplegic and paraplegic patients. Scand J Rehab Med 1971;3"141-150.

11. Leith D E. Cough. Phys Ther 1968;48:439-447.

12. Haas F, Axen K, Pineda H, Gandino D, Haas A. Temporal pulmonary function changes in cervical cord injury. Arch Phys Med Rehabil 1985;66:139-144.

13. Guttman L, Silver J. Electromyographic studies on reflex activity of the intercostals and abdominal muscles in cervical cord lesion. Paraplegia $1865 ; 3: 1$.

14. Tobin M J. Respiratory muscles in disease. Clinics in Chest Medicine 1988;9(2):264-286.

15. Estenne M, De Troyer A. Relationship between respiratory muscle electromyogram and rib cage motion in tetraplegia. Am Rev Respir Dis 1985; 132:53-59.

16. De Troyer A, Estenne M, Heilporn A. Mechanism of active expiration in tetraplegic subjects. N Engl J Med 1986;314(12):740-744.

17. Cheshire D J E. Respiratory management in acute tetraplegia. Paraplegia 1964;1:252-261.

18. McMichan J C, Michel L, Westbrook P R. Pulmonary dysfunction following traumatic quadriplegia : recognition, prevention and treatment. JAMA 1980;243:528-531.

19. Fugl-Meyer A R, Grimsby G. Ventilatory function in tetraplegic patients. Scand J Rehabil Med MD 1971;3:151-160.

20. Forner J V. Lung volumes and mechanics of breathing in tetraplegia. Paraplegia 1980;18:258-266.

21. Ledsome J R, Sharp J M. Pulmonary function in acute cervical cord injury. Am Rev Respir Dis 1981;124:41-44.

22. Bergofsky $E H$. Mechanism for respiratory insufficiency after cervical cord injury. Ann Intern Med 1964;61:435-447.

23. Engel W K The essentiality of histo-and cyto-chemical studies of skeletal muscles in the investigation of neuromuscular disease. Neurology 1972;12:778-794.

24 Axel R, Fugl-Meyer A R, Grimsby G. Respiration in tetraplegia and hemiplegia: a review. Int Rehab Med 1984;6:186-190.

25. Gounden P. Ventilatory muscle training. Proceedings of Congress of S A Society of Physiotherapy, Johannesburg 1985. 